\title{
Proximate Constitution and Antiproliferative Activity of Pleurotus opuntiae (Durieu and Lev.) Sacc. against Colon Cancer
}

\author{
P.J. Krishnapriya* and D. Geetha \\ Department of Plant Pathology, College of Agriculture, \\ Kerala Agricultural University, Trissur, India \\ *Corresponding author
}

\begin{tabular}{|c|c|}
\hline & A B S T R A C T \\
\hline & \multirow{5}{*}{$\begin{array}{l}\text { Pleurotus opuntiae owing to its short duration, pure white nature and ability to utilise the } \\
\text { locally available substrates make it a promising oyster mushroom species, which can } \\
\text { revolutionize the mushroom farming. The particular variety, isolated from arecanut tree } \\
\text { (Areca catechu L.) logs was confirmed by ITS sequencing and registered at Genbank } \\
\text { database (accession number: KY214255). Awareness of the nutritional and medicinal } \\
\text { importance of } P \text {. opuntiae is not extensive. Proximate constituents of the harvested } \\
\text { sporocarps, viz., moisture, carbohydrates, protein, fat, fibre, ash, lipids and polysaccharides } \\
\text { viz., cellulose, starch, reducing sugars were analysed. The results indicated the presence of } \\
\text { significant nutritional quantities viz., high amount of moisture }(90.70 \%) \text {, carbohydrates } \\
\text { ( } 46.13 \%) \text {, protein }(19.96 \%) \text {, fat ( } 2.2 \%) \text {, fibre }(9.68 \%) \text {, ash }(6.09 \%) \text {, lipids ( } 3.88 \%) \text {, } \\
\text { cellulose (11.26), starch }(7.5) \text { and reducing sugars }(6.31 \%) \text {. Anti-cancer activity of the } \\
\text { mushroom, was analysed using MTT (Microculture Tetrazolium Assay), against HT-29 } \\
\text { (human colon adenocarcinoma) cell line at five different concentrations of dried } \\
\text { mushroom extract }(6.25,12.5,25,50,100 \mu g / m l) \text {. Dried extract of mushroom at } 100 \mu \mathrm{g} / \mathrm{ml} \text {, } \\
\text { recorded the highest anti-proliferative effect, with least absorbance }(0.641) \text { at } 540 \mathrm{~nm} \text { and } \\
\text { minimum cell viability }(29.27 \%) \text {. Rounding or shrinking of cells, granulation and } \\
\text { vacuolization in the cytoplasm of the cancer cell lines were observed as indicators of } \\
\text { cytotoxicity. }\end{array}$} \\
\hline $\begin{array}{l}\text { Pleurotus opuntiae, } \\
\text { proximate } \\
\text { constituents, } \\
\text { anticancer, } \\
\text { MTT assay. }\end{array}$ & \\
\hline Article Info & \\
\hline & \\
\hline & \\
\hline
\end{tabular}

\section{Introduction}

Mushroom is a macrofungus with a distinctive fruiting body which can be either epigeous or hypogeous and large enough to be seen with naked eye and picked by hand (Eliott, 1985). Mushrooms have long been appreciated as an important source of bioactive compounds of medicinal value. The nutritional value of mushrooms depends on their chemical composition. Pleurotus mushroom, generally referred as the 'oyster mushroom' or 'Dhingri', is the well appreciated one in Kerala, for its broad adaptability under diverse agro-climatic conditions. Oyster mushrooms are generally considered nutraceutical and are rich in antioxidants, dietary proteins, fibres, vitamins and minerals. There are 15 to 20 species of oyster mushrooms available for cultivation in Kerala, of which the popular ones are Pleurotus florida, Pleurotus sajorcaju and Pleurotus citrinopileatus. 
A new addition to the Pleurotus family, is the newly identified Pleurotus opuntiae, with the shortest duration among the Pleurotus genus. Sporocarp masses of Pleurotus opuntiae looked so much like angelic wings flapped around the mushroom beds. Sporocarps are stark white, delicately fringed at the edges, borne on short stalks. Also, a characteristic thick white patch can be seen at the centre of sporocarps.

Mushrooms have a great nutritional value since they are quite rich in protein, essential amino acids, fiber and poor in fat. It is a good source of vitamin B-complex and Vitamin C. It is the only vegetable source of Vitamin D. It is rich in minerals like copper (cardioprotective) and Selenium (anti-cancer) (Kakon et al., 2012).

Cancer, medically known as malignant neoplasm, is a broad group of diseases involving unregulated cell growth. In cancer, cells divide and grow uncontrollably, forming malignant tumors, and invading multiple organs. Cancer is a leading cause of death worldwide. Many management options for cancer are available, viz., surgery, chemotherapy, radiation therapy and palliative care. Treatment options often are expensive and have side effects. This situation has resulted, in the search for new antitumor substances, from various natural sources for effective and safer control (Chung et al., 2010).

Many compounds have been isolated from mushrooms with anti-tumour effects such as, lentin, a polysaccharide isolated from Lentinusedodes, against sarcoma and hepatoma cells (Yamaguchi et al., 2011). The bioactive compounds of mushrooms can complement classical cancer therapy and counter the side-effects of cancer, such as nausea, bone marrow suppression, anaemia etc.
In this context, the present study aims at the estimation of proximate constituents of oyster mushroom- $P$. opuntiae. Here, MTT assay was used to determine cytotoxic effect of the dried mushroom extract, in order to define whether active compounds destabilize the membrane or inhibit mitochondrial activity.

\section{Materials and Methods}

\section{Sample collection}

The particular variety, isolated from arecanut tree (Areca catechu L.) logs was confirmed by ITS sequencing, using universal primers of ITS and registered at Genbank database (accession number: KY214255). The isolate was brought into pure culture on potato dextrose agar medium, followed by spawn preparation on paddy grains. Cultivation trials were undertaken with paddy straw as substrate, using polybag method of cultivation. Fully matured sporocarps were harvested and kept for moisture estimation. Another set of sporocarps were cleaned with distilled water, mechanically dried and powdered, for the estimation of other proximate constituents.

\section{Estimation of proximate constituents}

Estimation of proximate constituents viz., protein, moisture, carbohydrates, fat, fibre, lipid, and ash were done, using AOAC procedures (AOAC, 1995) method. Estimation of moisture content was done on fresh weight basis. All the other analysis was done on dry weight basis.

\section{Estimation of polysaccharides}

Estimation of polysaccharides were done viz., starch by anthrone reagent (Hodge and Hofreiter, 1962), cellulose (Updegroff, 1969) and reducing sugar by dinitrosalicylic acid method (Miller, 1972), using dried, powdered mushroom sample. 
Anticancer/in vitro antiproliferative effect by MTT ASSAY

\section{Maintenance of human colon cancer cell line}

Human colon carcinoma cell line was used to test the cytotoxic activity of $P$. opuntiae dried mushroom extract. HT-29 (human colon adenocarcinoma) cell line was initially procured from National Centre for Cell Sciences (NCCS), Pune, India and maintained in Dulbecos modified Eagles medium (DMEM) (Gibco, Invitrogen). The cell line was cultured in $25 \mathrm{~cm}^{2}$ tissue culture flask containing DMEM, supplemented with $10 \%$ FBS, L-glutamine, sodium bicarbonate and antibiotic solution containing: penicillin $(100 \mu \mathrm{g} / \mathrm{ml})$, streptomycin $(100 \mu \mathrm{g} / \mathrm{ml})$, and amphotericin B $(2.5 \mu \mathrm{g} / \mathrm{ml})$. Cultured cell lines were kept at $37^{\circ} \mathrm{C}$ in a humidified $5 \%$ $\mathrm{CO}_{2}$ incubator (NBS Eppendorf, Germany).

The viability of cells was evaluated by direct observation of cells by Inverted phase contrast microscope, followed by MTT assay method.

\section{Cells seeding in 96 well plate}

Two days old confluent monolayer of cells was trypsinized and the cells were suspended in $10 \%$ growth medium. $100 \mu 1$ cell suspension $\left(5 \times 10^{4}\right.$ cells/well $)$ was seeded in 96 well tissue culture plate and incubated at $37^{\circ} \mathrm{C}$ in a humidified $5 \% \mathrm{CO}_{2}$ incubator.

\section{Preparation of mushroom extract and compound stock}

$1 \mathrm{mg}$ of dried mushroom powder was added to $1 \mathrm{ml}$ of DMEM and dissolved completely by cyclomixer. The extract solution was then filtered through $0.22 \mu \mathrm{m}$ millipore syringe filter, to ensure the sterility.
Evaluation of antiproliferative effect by direct microscopic observation

The growth medium was removed after 24 hours. Freshly prepared samples in 5\% DMEM were five times serially diluted by two fold dilution $(100 \mu \mathrm{g}, 50 \mu \mathrm{g}, 25 \mu \mathrm{g}$, $12.5 \mu \mathrm{g}, 6.25 \mu \mathrm{g}$ in $100 \mu 1$ of $5 \% \mathrm{MEM})$. Each concentration of $100 \mu \mathrm{l}$, were added in triplicates, to the respective wells and incubated at $37^{\circ} \mathrm{C}$ in a humidified $5 \%$ carbondioxide incubator. Entire plate was observed at an interval of 24 hours; up to 72 hours in an inverted phase contrast tissue culture microscope (Olympus CKX41 with Optika Pro5 CCD camera).Microscopic observation were recorded as images. Any detectable changes in the morphology of the cells, such as rounding or shrinking of cells, granulation and vacuolization in the cytoplasm of the cells were considered as indicators of cytotoxicity.

\section{Evaluation of antiproliferative effect by} MTT assay

MTT (3-(4,5-Dimethylthiazol-2-yl)-2,5Diphenyltetrazolium Bromide)(Sigma, M-5655) (15mg) was reconstituted in $3 \mathrm{ml}$ of phosphate buffer saline, until completely dissolved and sterilized by filter sterilization. After 24 hours of incubation, the sample content in wells were removed and $30 \mu 1$ of reconstituted MTT solution was added to all the test and cell control wells. The plate was gently shaken, then incubated at $37^{\circ} \mathrm{C}$ in a humidified 5\% carbondioxide incubator for 4 hours. After the incubation period, the supernatant was removed and $100 \mu \mathrm{l}$ of MTT solubilization solution (DMSO) was added. The wells were mixed gently by pipetting up and down, in order to solubilize the formazan crystals. The absorbance values were measured by using microplate reader, at a wavelength of $570 \mathrm{~nm}$ (Talarico et al., 2004). Each concentration was tested in triplicate. 
The percentage of growth inhibition was calculated using the formula:

$$
\% \text { of cell viability }=
$$

\section{Results and Discussion}

\section{Sample collection}

P. opuntiae isolated from areacanut tree logs, took 7 days for complete coverage of petriplate, when potato dextrose peptone agar was used as medium (Fig. 1). PCR amplification using ITS universal primers, gave an amplicon of size 657bp (Fig. 2).

Spawn run of $P$. opuntiae was completed on paddy grains within 10-11 days (Fig. 3). The mushroom took 8 days for complete spawn run, 9 days for pin head formation and 12 days for the first harvest (Fig. 4), when paddy straw was used as substrate for mushroom bed preparation. Around 750-800g of sporocarps were obtained from $1 \mathrm{~kg}$ of the substrate.

\section{Estimation of proximate constituents}

Proximate analysis was carried out on fresh and dried samples of $P$. opuntiae. Results of the proximate composition are presented in table 1 .

Generally the, moisture contents of the mushroom are high, indicating that mushrooms are highly perishable. High moisture content promotes susceptibility to microbial growth and enzyme activity. The study revealed that, $90.70 \%$ moisture was present in P. opuntiae (Zhang et al., 2007). The results indicated, the presence of significant nutritional quantities viz., high amount of carbohydrates (46.13\%), protein $(19.96 \%)$, fat $(2.2 \%)$, fibre $(9.68 \%)$, ash (6.09) and lipids (3.88\%). The proximate constitution recorded, was comparable, with
Mean OD Samples x 100

\section{Mean OD of control group}

those reported for legumes, except for groundnut and soyabeans (Aletor and Aladetimi, 1995). Results were in agreement with those reported by other workers (Shashirekha, 2005; Jaworska and Bernas, 2011). Ogundana and Fagade (1981) indicated that mushroom contains $16.5 \%$ dry matter, out of which $7.4 \%$ is crude fibre, $14.6 \%$ is crude protein and $4.48 \%$ is fat and oil.

\section{Estimation of polysaccharides}

Reducing sugars, non-reducing sugars and total sugars of mushrooms, contributes for the expansion of fruit bodies and determine their nutritional quality. Polysaccharides are the best known and potent mushroom-derived antitumor/immunomodulating substances. Polysaccharide constitution of oyster mushrooms are presented in table 2 and the results are in conformation with the work of Jahangir et al., 2015.The present work, indicated the presence of significant amount of polysaccharides viz., cellulose $(11.26 \%)$, starch $(7.50 \%)$ and reducing sugars $(6.31 \%)$.

\section{Anticancer/in vitro antiproliferative effect by MTT ASSAY}

The MTT (Microculture Tetrazolium Assay) or in vitro cell proliferation assay is one of the most widely used assays, for evaluating preliminary anticancer activity of both synthetic derivatives and natural products. The highly reliable, colorimetric based assay is readily performed on a wide range of cell lines. This assay gives an indication of whole cell cytotoxicity (Cauley et al., 2013). 
Table.1 Proximate analysis of $P$. opuntiae

\begin{tabular}{|l|c|}
\hline Proximate constituents & *Quantity present (\%) \\
\hline Moisture & 90.70 \\
\hline Carbohydrate & 46.13 \\
\hline Protein & 19.96 \\
\hline Fat & 2.20 \\
\hline Lipids & 3.88 \\
\hline Fibre & 9.68 \\
\hline Ash & 6.09 \\
\hline
\end{tabular}

*Average of three replications

Table.2 Polysaccharide analysis of $P$. opuntiae

\begin{tabular}{|l|l|}
\hline Polysaccharides & *Quantity present (\%) \\
\hline Reducing sugars & 6.31 \\
\hline Starch & 7.50 \\
\hline Cellulose & 11.26 \\
\hline
\end{tabular}

*Average of three replications

Table.3 In vitro antiproliferative activity of $P$. opuntiae extract against colon cancer cell line

\begin{tabular}{|l|l|l|}
\hline $\begin{array}{l}\text { Sample Concentration } \\
(\boldsymbol{\mu g} / \mathbf{m l})\end{array}$ & $\begin{array}{l}\text { *Absorbance } \\
\text { at 540nm }\end{array}$ & $\begin{array}{l}\text { *Percentage } \\
\text { Viability }\end{array}$ \\
\hline Control & 2.189 & 100 \\
\hline P. opuntiae extracts & & \\
\hline 6.25 & 1.942 & 88.726 \\
\hline 12.5 & 1.620 & 74.029 \\
\hline 25 & 1.253 & 57.240 \\
\hline 50 & 1.026 & 46.886 \\
\hline 100 & 0.641 & 29.270 \\
\hline
\end{tabular}

LD 50 VALUE (g2) - 55.039 $\mu \mathrm{g} / \mathrm{ml}$

*Average of three replications 
Fig. 1 \& 2 P. opuntiae culture and PCR amplicon of $P$. opuntiae using ITS primers

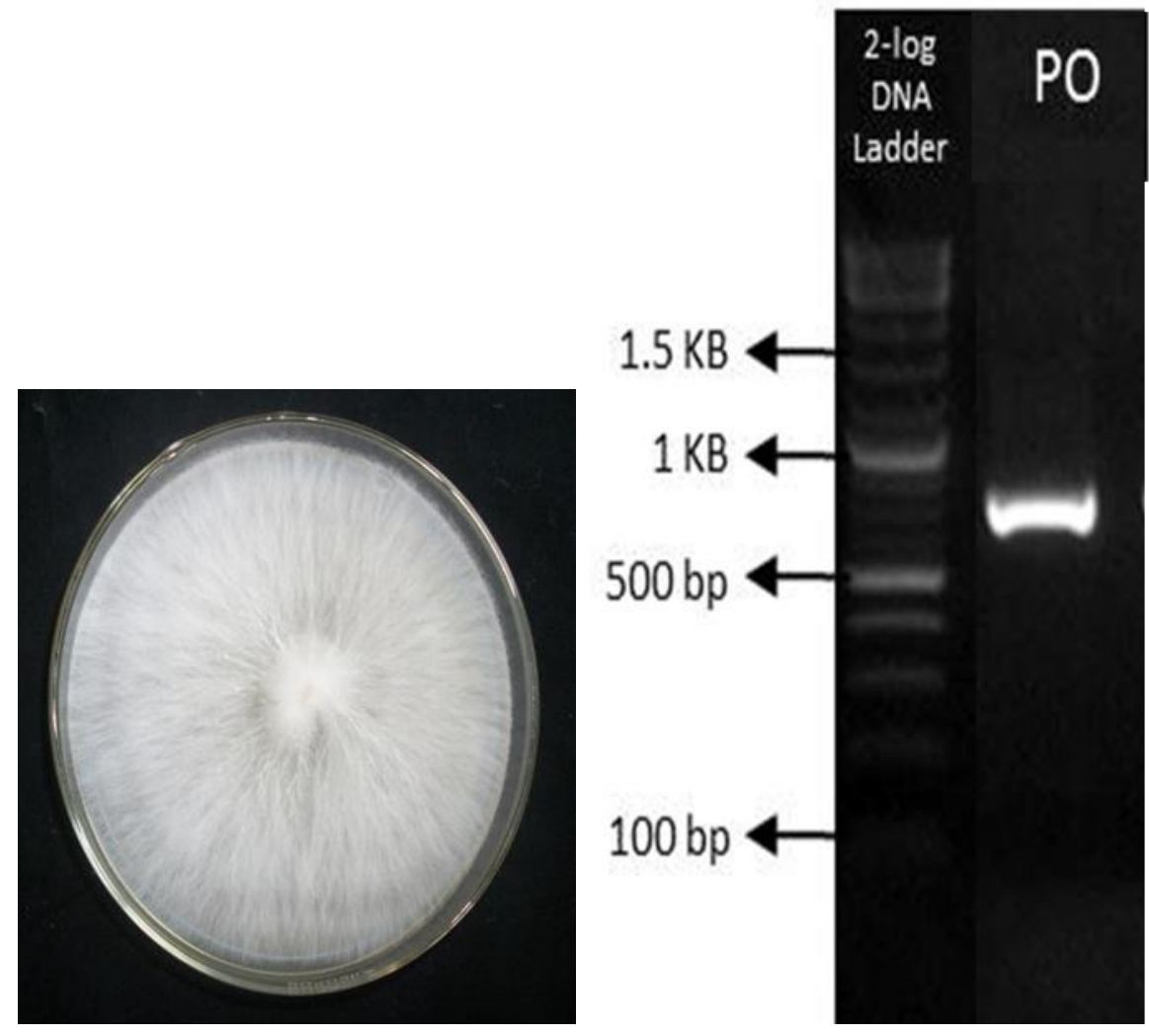

Fig.3\&4 Spawn of $P$. opuntiae and Mature sporocarps of $P$. opuntiae
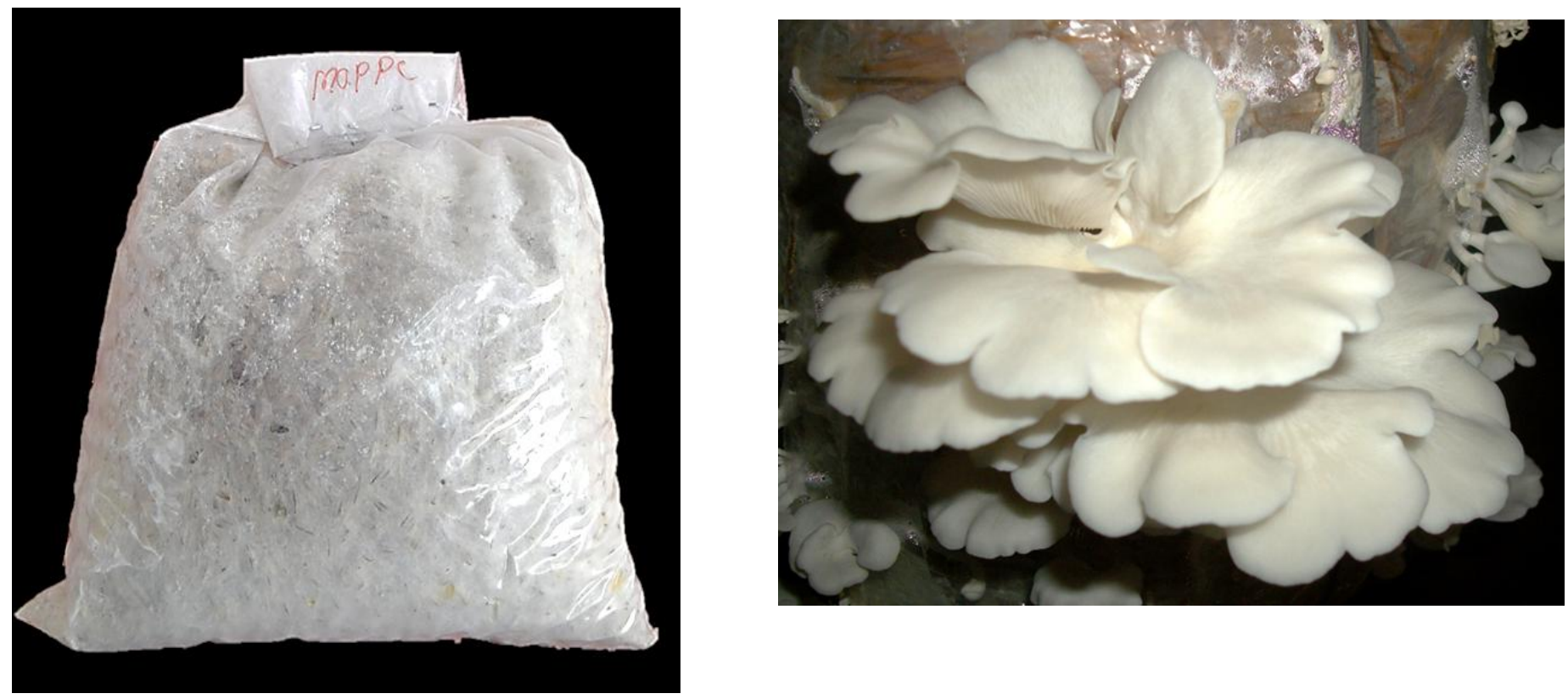
Fig.5 Microscopic observations of colon cancer cell lines treated with varied concentrations of $P$. opuntiae extracts

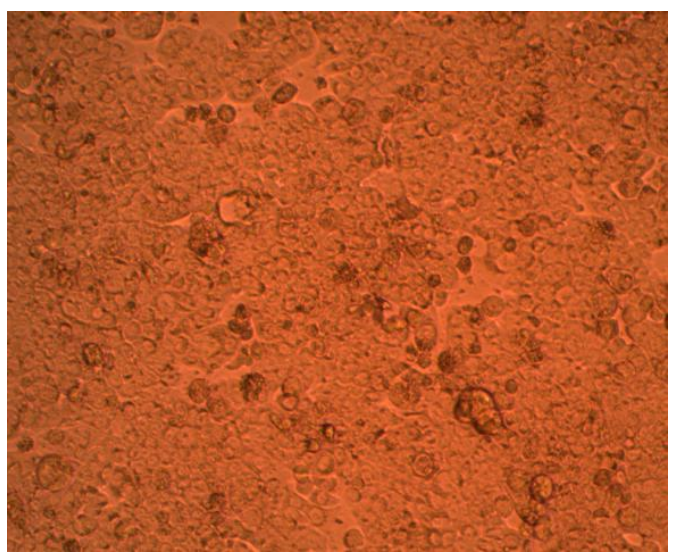

$6.25 \mu \mathrm{g} / \mathrm{ml}$

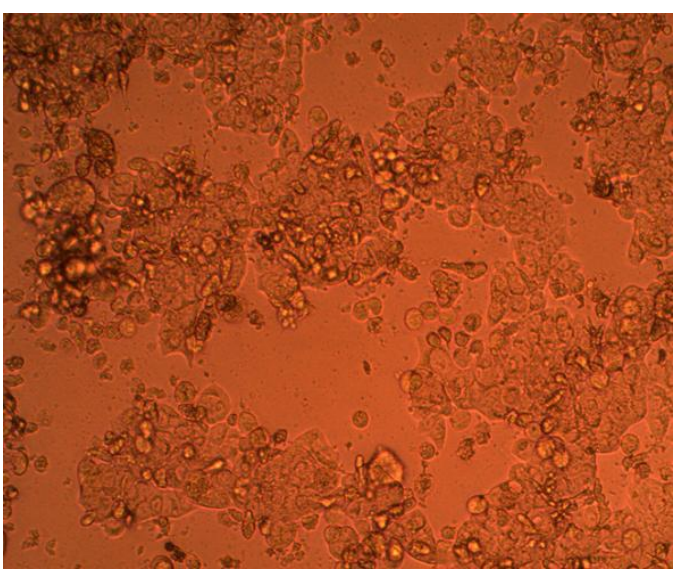

$12.50 \mu \mathrm{g} / \mathrm{ml}$

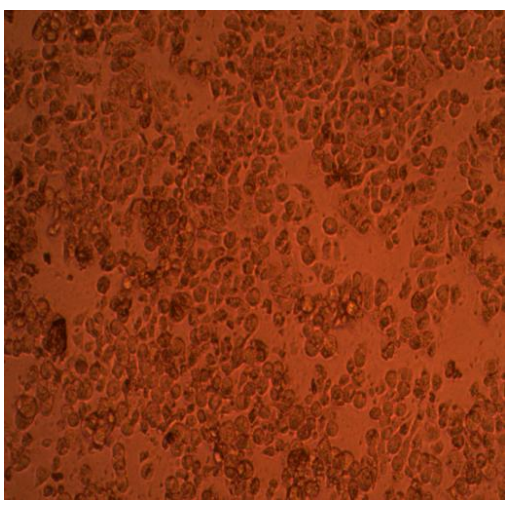

$25.00 \mu \mathrm{g} / \mathrm{ml}$

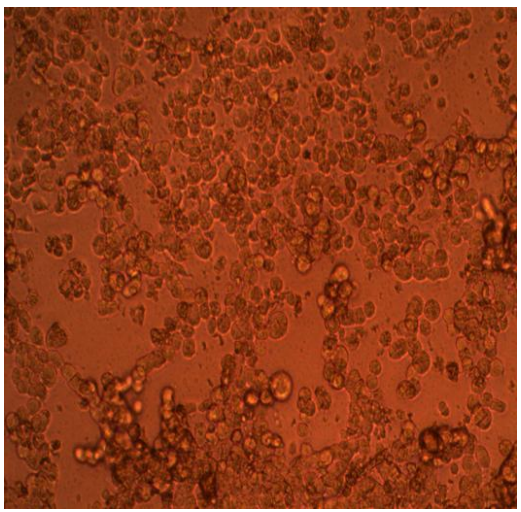

$50.00 \mu \mathrm{g} / \mathrm{ml}$

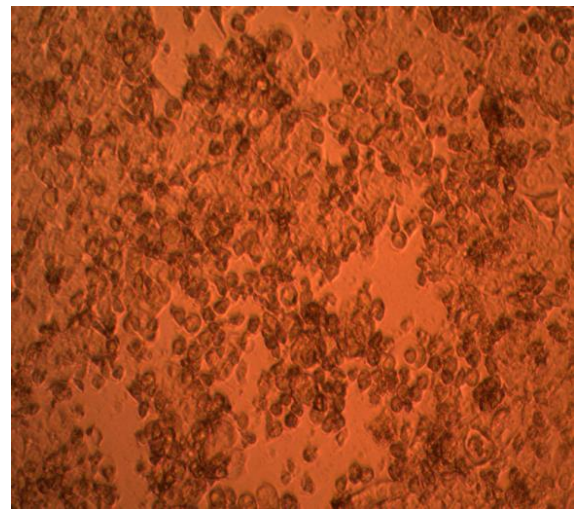

$100.00 \mu \mathrm{g} / \mathrm{ml}$
The viability of colon cancer cells treated with $P$. opuntiae extract, reduced in a concentration dependent manner (Table 3). Higher extract concentrations exhibited stronger anticancer activity. Dried extract of mushroom at concentration of $100 \mu \mathrm{g} / \mathrm{ml}$ recorded the highest anti-proliferative effect, with least absorbance (0.641) at $540 \mathrm{~nm}$ and minimum cell viability $(29.27 \%)$. On direct microscopic observations (Fig. 5), detectable changes in the morphology of the cells, such as rounding or shrinking of cells, granulation and vacuolization in the cytoplasm of the cells were recorded, as indicators of cytotoxicity.
Intensity of cytotoxicity increased with the concentration of dried mushroom extract. The LD- 50 value was found as $55.039 \mu \mathrm{g} / \mathrm{ml}$ i.e. concentration of extract needed for the 50\% of cell death. Results indicated that, $P$. opuntiae extract had significant antiproliferative activity against colon cancer cell lines.

A possible explanation of observed cytotoxic effects lies in the fact that, polysaccharide extracts of various mushrooms are highly active in reactive oxygen species (ROS) generation (Durgo et al., 2013). The results of 
the current work, are consistent with the studies demonstrating that, basidiomycetes have antitumor activity by direct or indirect mechanisms (Talarico et al., 2005).

In conclusion, this study contributes to the elaboration of nutritional and medicinal databases of the most consumed fungi species worldwide, allowing comparison between them. The observed levels of the proximate compositions of $P$. opuntiae, indicates its prospects, in complementing the nutrient supply deficits, prevalent in developing countries. The species can be recommended for the countries suffering from malnutrition; especially developing or third world countries. Dried mushroom extract of $P$. opuntiae showed significant anti-proliferative effect on colon cancer cell line. In the present context, future work is needed to determine, the effects of P.opuntiae extract on animals/humans in vivo. Although cancer therapies can inhibit tumour growth and prolong the life span of humans, they usually compromise the immune system and damage genetic material of healthy cells. Thus, supportive biotherapy, using $P$. opuntiae extracts, is a promising alternative/supplement to conventional cancer therapies.

\section{References}

Aletor, V.A. and Aladetimi, O.O. 1995. Compositional studies on edible tropical species of mushrooms. Food Chemi, 54(3): 265-268.

AOAC. 1995. Official methods of analysis (16th Ed.). Arlington VA, USA: Association (of Official Analytical Chemists,

Cauley, J., Zivanovic, A. and Skropeta, D. 2013. Bioassays for Anticancer Activities. Methods in Mol. Biol., 1055:191-205.

Chung, C.K., Jeong,Y. and Ham, S.S., Anticancer activity of subfractions containing pure compounds of Chaga mushroom (Inonotusobliquus) extract in human cancer cells and in Balbc/c mice bearing Sarcoma-180 cells. Nutrition Res. Practice, 4: 177-182.

Durgo, K., Koncar, M., Komes, D., Franekic, J., Jakopovich, I., Jakopovich, N. and Jakopovich, B. 2013. Cytotoxicity of blended versus single medicinal mushroom extracts on human cancer cell lines: Contribution of polyphenol and polysaccharide content. Int. J. Med. Mushrooms, 15(5): 435-448.

Eliott, T.J. 1985. Spawn making and spawns. In: Flegg, P.B., Spencer, D.M., and Wood, D.A. (eds), The Biology and Technology of the Cultivated mushrooms. John Wiley \& Sons, New York, pp. 131-139.

Hedge, J.E. and Hofreiter, B.T. 1962. In: Carbohydrate Chemistry, 17 (Eds. Whistler R.L. and Be Miller, J.N.), Academic Press, New York.

Jahangir, M.M., Samin, G., Khan, N.A., Rehman, A., Aslam, Z. and Amjad, M. 2015. Performance of oyster mushroom (Pleurotusostreatus) grown on cotton waste and sorghum straw based growing substrates. Pakistan J. Phytopathol., 27(01): 77-81.

Jaworska, G. and Bernaś, E. 2011. Comparison of amino acid content in canned Pleurotusostreatus and Agaricusbisporus mushrooms. Vegetable Crops Res. Bull., 74: 107-115.

Kakon, A.J., Karim, B.C. and Saha, S. 2012. Mushroom is an Ideal Food Supplement. J. Dhaka Nat. Med. College and Hospital, 18 (1): 58-62.

Miller, G.L. 1972. Anal. Chem., 426: 31 p.

Ogundana, S.K. and Fagade, O. 1981. The nutritive value of some Nigerian edible mushrooms. In: Mushroom Science XI, Proceedings of the Eleventh International Scientific Congress on the 
cultivation of edible fungi, Australia. $\mathrm{pp}$ 123-131.

Shashirekha, M.N., Rajarathnam, S. and Bano, Z. 2005. Effects of supplementing rice straw growth substrate with cotton seeds on the analytical characteristics of the mushroom, Pleurotusorida (Block \&Tsao). Food Chem., 92(2): 255-259.

Talarico, L.B., Pujol, C.A., Zibetti, R.G., Faria, P.C., Noseda, M.D. and Duarte, M.E. 2005. The antiviral activity of sulfated polysaccharides against dengue virus is dependent on virus serotype and host cell. Antiviral Res., 66(2-3): 103110.
Updegroff. 1969. Semi micro determination of cellulose in biological materials. Anal. Biochem., 32(3): 420-424.

Yamaguchi, Y., Miyahara,E. and Hihara J. 2011. Efficacy and safety of orally administered Lentinulaedodes mycelia extract for patients undergoing cancer chemotherapy: a pilot study. American J. Chinese Med., 39: 451-459.

Zhang, M., Cui, S.W., Cheung, P.C.K. and Wang, Q. 2007. Antitumor polysaccharides from mushrooms: a review on their isolation process, structural characteristics and antitumor activity. Trends in Food Sci. Technol., 18:

\section{How to cite this article:}

Krishnapriya, P.J., and Geetha, D. 2017. Proximate Constitution and Antiproliferative Activity of Pleurotus opuntiae (Durieu and Lev.) Sacc. against Colon Cancer. Int.J.Curr.Microbiol.App.Sci. 6(5): 1406-1414. doi: https://doi.org/10.20546/ijcmas.2017.605.153 